\title{
INFLUENCE OF INSTITUTIONAL OWNERSHIP AND UTILIZATION OF TAX HAVEN TO THIN CAPITALIZATION
}

\author{
Nofryanti, Tuti Nurjanah \\ Universitas Pamulang \\ nofryanti@unpam.ac.id
}

\begin{abstract}
This study aims to find out the influence of instituonal ownewrship and utilization of tax haven and with Thin capitalization. Sample in this study is 21 with criterias: manufacturing companies in indonesia stoct exchange for the periode 212-2016. Analysis were conducted byusing multiple regression analysis. The result shows that instituonal ownweship has negative influence on thin capitalization, while the utilization of tax haven has no significant influence on thin capitalization.
\end{abstract}

Keywords: thin capitalization, Institutional Ownership tax haven.

\section{INTRODUCTION}

The development of the business world will have an impact on very tight competition to attract foreign investors to invest their capital in a country. To attract investors, the country must be active in promoting its country so that it becomes the choice of investors to invest their capital. Darmawan (2016) states that the main problem for investors in investing their capital is providing incentives, which are related to the tax regulations of the country concerned. With this incentive, it is hoped that there will be many investors from outside countries who come to invest, so that it can increase state revenues, especially income in the taxation sector.

In Indonesia, in the taxation sector, the government seeks to maximize state revenues, namely by increasing the number of tax objects by accepting foreign investors to invest in Indonesia. Darmawan (2016) states that taxation on the benefit theory of taxation is sourced from the income of foreign entities in the country due to the existence of an economic attachment between Source State (the source country), namely Indonesia which raises income from its activists. Sources of income obtained by foreign companies can be a source of income for Indonesia in the form of taxes, as well as for countries of origin of foreign companies that also have rights to income tax originating from Indonesia due to relations between countries and tax subjects in their countries. This makes Indonesia get tax revenues from foreign entities or foreign investors.

In practice the problems commonly experienced by a country for the taxation sector, namely the efforts of private taxpayers and agencies to reduce or even nullify the tax burden that must be paid. This is usually done by taxpayers, namely in the form of utilization of opportunities in the form of tax savings and tax avoidance that are 
legally valid. So that the efforts of taxpayers to reduce taxes can be an obstacle for governments in developing countries such as Indonesia who are trying to increase income in the taxation sector

In Nuraini (2014), Mortenson states that tax avoidance is a way to reduce or even eliminate the tax burden that arises. In the Tax Law the efforts of taxpayers to make efforts to reduce, avoid so that this tax burden is reduced is possible, so it does not include tax violations. The existence of this effort has finally made state revenues, especially in the tax sector, decline and not according to the target set by the government each year.

Thin capitalization is one of the methods used by taxpayers or companies avoiding high taxes, by making corporate debt higher than their capital. The debt is used to fund the company's operations. According to the 2012 OECD (Organization for Economic Cooperation Development), the practice of thin capitalization is the condition of a company using more debt than its own capital as a source of funding (Lubis, 2017). Desai (2004) states that multinational companies use international debt transfers to save tax payments by utilizing differences in national tax rates and preferential tax rules.

This study discusses the factors that influence thin capitalization, such as Nuraini (2014) and Darmawan (2016) research as a differentiator in this study, namely by only focusing on the independent variables of institutional ownership and utilization of tax havens. The use of manufacturing companies in this research sample is because the components in financial statements are more complete than service companies and are in accordance with the needs of researchers. The selection of the last five years range of time from the initial year of this study in order to provide updated results according to the latest conditions of how the company activities take place

\section{LITERATURE REVIEW}

\subsection{Agency Theory.}

Jensen and Meckling (1976) in the study of Zelmiyanti (2016) stated that, agency relations is a contract between the principal and the agent, by looking at the delegation of some decision-making authority to the agent. Where the agent has the responsibility to provide great benefits to the principal, but on the other hand the agent also has the desire to fulfill his own interests.

Agency theory can be assumed that the existence of different objectives between the principal and the agent creates a conflict between the two, because company managers are more likely to pursue personal gain. So that this can lead to companies that want high profits through ways to minimize taxes that will be paid through tax planning. One of the tax planning that can be done is by practicing thin capitalization, while tax authorities keep calculating the income tax of a company in accordance with the provisions of the applicable law.

Thin capitalization which is part of tax planning related to agency theory because of differences or conflicts in it. This difference is found in the purpose between the agent and the principal. In terms of fulfilling their own interests, the agents carry out tax avoidance (tax planning) in several ways, one of which is thin capitalization. With thin capitalization, agents benefit more than usual.

\subsection{Theory Of Planned Behavior.}

According to Rahayu (2010: 141) in the study of Azizah et al (2016), states that the behavior of taxpayers is a taxpayer characteristic reflected by the culture, social and economy that is reflected in their level of awareness in paying taxes. These theories can assume that, the 
emergence of intentions from a taxpayer or company to avoid such practices as thin capitalization is due to the attitude of individuals who are accustomed to violating norms or culture. Then social pressure can influence the emergence of the desire to fulfill personal benefits through the practice of thin capitalization, for example wishing to have a luxury vehicle such as the people around him or the demands of families who have luxurious living habits. This creates a strong desire so that it is not able to control its behavior so that it continues to act in accordance with existing rules. So that to meet personal interests by obtaining more profits than they should then the taxpayer practices tax avoidance.

\subsection{Thin Capitalization.}

In the practice of thin capitalization, it usually involves a holding company or commonly known as a holding company in a country with a low tax rate. So, this is used to divert taxes to the country which should be an income for Indonesia. The way to do this is to finance the subsidiary or commonly known as a subsidiary, where the parent company contributes by providing funds that are recorded as debt loans not capital. So that the subsidiary has a cost of interest, which later can reduce the tax that must be paid because the interest costs become a deduction in calculating taxable income.

In an effort to avoid and identify the existence of tax avoidance practices by means of thin capitalization or tax evasion, each country usually makes tax laws and regulations with the following conditions:

1. SAAR (Specific Anti Avoidance Rule), namely anti tax avoidance provisions for transactions such as: transfer pricing, thin capitalization, treaty shopping, and CFC (Controlled Foreign Corporation).
2. GAAR (General Anti Avoidance Rule), which is a general preventive tax avoidance provision with the aim of anticipating tax avoidance practices that have not been regulated in SAAR.

\subsection{Institutional Ownership.}

According to Oktofian (2015) states that institutional ownership has the ability to reduce the incentives of selfish managers through intense levels of supervision. Institutional ownership can reduce the tendency of management to utilize discretionary in financial statements so as to provide the quality of reported earnings. With effective supervision, earnings management actions will decrease. Presentations of shares held by institutions can affect the accrualization of financial statements in the interests of management.

In addition to the benefits or institutional capabilities in a company, namely as a provider of capital, this is also useful for increasing supervision that can be more optimal for management performance in the company. Where these institutions have more shares than other shareholders, so they have the authority to oversee the performance and management policies more, so that it can make management avoid behavior that can harm shareholders. And this institution is also more capable of detecting errors that occur because it is more experienced than individual shareholders.

\subsection{Utilization of Tax Haven.}

Nuraini (2014) explained about tax havens in the Income Tax Law, namely in article 18 (3c) of Law $\mathrm{PPh}$ number 36 of 2008 as follows: "Sales or transfer of shares of an intermediary company (conduit company or special purpose company) established or domiciled in a country that provides tax haven country that has a special relationship with an 
entity established or domiciled in Indonesia or a permanent establishment in Indonesia, it can be determined as the sale or transfer of shares of a body established or domiciled in Indonesia or a permanent establishment in Indonesia.".

There are four criteria in classifying tax haven countries or not tax haven countries according to the OECD (Organization for Economic Cooperation Development), including:

1. Do not collect taxes or collect taxes in a certain nominal amount (not based on percentages) or tax rates are low.

2. There is no or ineffectiveness of the exchange of information mechanism. This country imposes strict regulations regarding confidential bank or business information, so that it cannot be informed to other parties except for special relationships or international agreements.

3. Absence of transparency in (closed) tax administration.

4. There is a ring fencing policy (there are differences in tax treatment for residents and nonresidents).

\section{RESEARCH METHOD}

Thin capitalization.

Restricted capitalization is used to make the capital structure smaller than the corporation's debt. The measures of the thin capitalization variables adopt the study by Taylor \& Richardson (2012) in (Pristyanova, 2017). Here's how to calculate it:

MAD ratio $=$ average debt $:$ company SHDA

- MAD ratio (Maximum Allowable Debt) or the maximum amount of interest payable that can cause interest deductions in one fiscal year

- $\quad$ SHDA $=($ average total assets non IBL) x $75 \%$

\section{Institutional Ownership.}

According to Bernandhi (2013), institutional ownership is the ownership of shares of a firm by institutions or institutions such as insurance companies, banks, investment companies and the property of other institutions. Institutional ownership variables (INST) are measured by the proportion of shares held by the institution at the end of the year indicated in the presentation (Laily, 2017). The formula is as follows:

$$
\begin{aligned}
& \text { INST } \\
& =\frac{\text { Jumlah saham institusional }}{\text { Jumlah saham yang beredar }} \times 100 \%
\end{aligned}
$$

\section{Utilization of Tax Haven}

The use of tax havens is one of the ways in which taxpayers can avoid or reduce the amount of tax to be paid. By utilizing tax haven country countries to move their income to these countries, so as to minimize the amount of tax that must be paid. Measurement of tax haven utilization variables (TAXHAV) is measured by dummy variables. Expressed 1 if the company has at least one subsidiary incorporated in a tax haven that is recognized in the OECD (Organization for Economic Cooperation and Development), otherwise it is declared 0 if it does not exist, according to Taylor and Richardson (2012) OECD namely international organizations consisting of several countries who accept the principles of representative democracy and a free market economy.

\section{Population and sample.}

In this study the population used is the financial statements of manufacturing companies listed on the Indonesia Stock Exchange (IDX) from 2012 to 2016 and financial reports obtained from the site www.idx.co.id. The sample selection method used is purposive sampling 
where the researcher takes into consideration by making certain criteria. In this study, 21 (twenty one) companies were obtained and in five years vulnerable time to 105 (serratus five) who met the criteria to be sampled. Furthermore, the sample that has been obtained will be measured using the calculation formulas that have been explained previously, then the results will be tested using the SPSS 22.0 application.

\section{RESULTS AND DISCUSSION}

This research has been carried out the classic assumption test on the regression model in this research. Here are the results of the asumsi klasik test in this research

Table 1

\begin{tabular}{|l|l|l|l|}
\hline Test & Test equipment & Result & Information \\
\hline Normality & Test & $\begin{array}{l}\text { The KS-Z value is greater } \\
\text { than } 0.05 \text {, which is 0.163. }\end{array}$ & Normal data \\
\hline Multicolinierity & Glejser test & $\begin{array}{l}\text { Tolerance is less than 0.10 } \\
\text { and the Variance Inflation } \\
\text { Factor }(\text { VIF }) \text { value is more } \\
\text { than } 10\end{array}$ & $\begin{array}{l}\text { Multicollinearity } \\
\text { does not occur }\end{array}$ \\
\hline Heteroscedasticity & $\begin{array}{l}\text { Significance of more than } \\
0.05 \text { is equal to 0.742 }\end{array}$ & $\begin{array}{l}\text { Heteroscedasticity } \\
\text { does not occur }\end{array}$ \\
\hline Autocorrelation & Durbin Watson $(D W$ & $\begin{array}{l}\text { The probability of the } \\
\text { Durbin Watson value is } \\
\text { more than 0.05, which is } \\
2.357 .\end{array}$ & $\begin{array}{l}\text { There } \\
\text { autocorrelation }\end{array}$ \\
\hline
\end{tabular}

Results of Multiple Linear Regression Analysis.

models. The following are the results of

This research is to test the hypothesis by using multiple regression analysis

Table. 2 Multiple Linear Regression Analysis Test Coefficients $^{a}$

\begin{tabular}{|c|c|c|c|c|c|c|}
\hline & \multirow[t]{2}{*}{ Model } & \multicolumn{2}{|c|}{$\begin{array}{c}\text { Unstandardized } \\
\text { Coefficients }\end{array}$} & \multirow{2}{*}{$\begin{array}{c}\begin{array}{c}\text { Standardized } \\
\text { Coefficients }\end{array} \\
\text { Beta }\end{array}$} & \multirow[t]{2}{*}{$\mathrm{t}$} & \multirow[t]{2}{*}{ Sig. } \\
\hline & & B & Std. Error & & & \\
\hline \multirow[t]{3}{*}{1} & (Constant) & 1,193 &, 121 & & 9,899 & ,000 \\
\hline & INST &,- 008 & ,002 &,- 401 & $-4,383$ &, 000 \\
\hline & TAXHAV &,- 034 & ,067 &,- 047 &,- 517 & ,607 \\
\hline
\end{tabular}

a. Dependent Variable: MAD testing the hypothesis. 
From table 2 above, it can be seen if the level of the coefficient of determination found in the Adjusted R Square column has a value of 0.153 or $15 \%$. This shows that institutional ownership variables and tax haven utilization are only able to provide $15 \%$ information about thin capitalization and the remaining $85 \%$ is explained by other variables not explained in this study. So it can be concluded that the level of ability of this regression model is quite good in explaining the dependent variable.

\subsection{Effect of institutional ownership on the Thin Capitalization.}

Institutional ownership in this research is symbolized by INST. Based on table 6 above, there is a significant value of 0,000 and $t$ with a negative value $(-4,383)$. Because the calculated significance value is smaller than the specified significance value $(0,000$ $<0,05)$, then the alternative hypothesis (H1). It means that institutional ownership partially has a negative effect on thin capitalization.

Institutional ownership has a negative influence on thin capitalization, this means that institutional ownership or institutional owners in the company have a negative effect on tax avoidance practices, especially the practice of thin capitalization. This is because the number of shares owned by the institution influences how much the rights of the institutions in power in regulating and controlling the company. However, still these institutions cannot regulate and control as a whole so that the company can run in accordance with the applicable rules and according to the wishes of the institutions. Where the institutions think the company has good if the amount of capital is greater than the amount of debt. Because institutions cannot control overall and directly, the management of the company can regulate the amount of capital and company debt. So that the management or company can still practice tax avoidance with the practice of thin capitalization which makes the amount of debt higher than capital.

Investors usually can only do limited control and oversight of the company so that companies, especially managerial parties focus more on the performance of the company without being able to force or pressure, depending on the number of shares held. Plus multinational companies in Indonesia are owned by many institutions. So this is one of the factors that makes institutional ownership negatively affect thin capitalization.

\subsection{Effects of Tax haven Utilization on Thin Capitalization}

The use of tax havens in this study is symbolized by TAXHAV. Based on table 4.10 above, the significance value of 0.607 and $t$ is negative $(-0.517)$. Because the calculated significance value is greater than the specified significance value $(0.607>0.05)$, then hypothesis 2 is rejected. It means that the utilization of tax havens partially has no significant effect on thin capitalization.

There is no relationship between the use of tax havens and thin capitalization. This could be due to different regulations regarding thin capitalization in each country. Where companies can do tax avoidance by utilizing the existence of a tax haven state. But doing tax avoidance practices with thin capitalization in tax haven countries is not necessarily possible.

Multinational companies take advantage of opportunities to practice tax avoidance. The existence of tax haven countries that impose low tax rates to be tax exempt is a haven for companies that want to get more profit. The usual way for companies to take advantage of tax havens is to invest in tax haven country and even establish a branch or subsidiary there to divert 
profits. By transferring profits earned to branch companies or by utilizing interest originating from debt loans of branch companies in tax haven countries it is also a common way to avoid taxes.

The practice of thin capitalization by making debt greater than capital can be done in several countries including Indonesia, but not all countries that have tax haven status can be due to differences in the rules regarding thin capitalization in each country. So, in other words, tax haven and thin capitalization in a country have their own rules, and are not interrelated

\section{CONCLUSSION}

Based on the results of the above research regarding the influence of

\section{REFERENCES}

Azizah, Devi Farah. Kartini, Dwi Aprilia, dan Suhadak. 2016. Pengaruh Persepsi Dan Perilaku Wajib Pajak Atas Penerapan EFiling Terhadap Kepatuhan Wajib Pajak Orang Pribadi.Universitas Brawijaya.

Bernandhi, Riza. 2013. Pengaruh Kepemilikan Manajerial, Kepemilikan Institusional, Kebijakan Dividen, Leverage Dan Ukuran Perusahaan Terhadap Nilai Perusahaan. Skripsi Diponegoro University.

Darmawan, Eric.2016. Analisis Pengaruh Multinationality, Pemanfaatan Tax Haven, Pemotongan Pajak (Withholding Taxes), Kepemilikan Institusional, Dan Ukuran Komite Audit Terhadap Praktik Thin Capitalization. Universitas Sumatera Utara.

Desai M.A., Foley C.F. and Hines J.R., 2004. A Multinational Perspective on Capital Structure Choice and institutional ownership and utilization of tax havens on thin capitalization in manufacturing companies listed on the Indonesia Stock Exchange (IDX) with the 2012-2016 research year, a number of things can be concluded as follows:

1. Based on the results of the above research, the results obtained for institutional ownership partially have a negative effect on thin capitalization.

2. Based on the results of the above research, partial results for the utilization of tax havens have no significant effect on thin capitalization.

Internal Capital Markets. Journal of Finance 59, 2451-2487.

Fransisca, Fioni. 2016. Pengaruh Pajak Dan Debt Convenant Terhadap Keputusan Perusahaan Untuk Melakukan Transfer Pricing. Skripsi Pamulang University.

Harinurdin, Erwin. 2009. Perilaku Kepatuhan Wajib Pajak Badan. Universitas Indonesia.

Ismi, Fadhil dan Linda. 2016. Pengaruh Thin Capitalization, Return On Asset, Dan Corporate Governance Pada Perusahaan Jakarta Islami Index (Jii). E- Jurnal Ilmiah Mahasiswa Ekonomi Akuntansi (JIMEKA).

Komariah, Nurul. 2017. Pengaruh Thin Capitalization Dan Karakter Eksekutif Dengan Kompensasi Manajemen Kunci Sebagai Pemoderasi Terhadap Penghindaran Pajak. Skripsi UIN Syarif Hidayatullah Jakarta.

Laily, Nur. 2017. Pengaruh Kepemilikan Institusional, Proporsi Dewan Komisaris, Leverage, Ukuran 
Perusahaan Dan Return On Asset Terhadap Penghindaran Pajak Pada Perusahaan Manufaktur. Artikel Ilmiah Sekolah Tinggi Ilmu Ekonomi Perbanas.

Lubis, Vina Mentari. 2017. Pengaruh Foreign Exposure, Multinationality, With Holding Taxes, Dan Kepemilikan Institusional Terhadap Praktik Thin Capitalization. Universitas Negeri Medan.

Mangoting, Yenny dan Wanarta, Feby Eileen. 2014. Pengaruh Sikap Ketidakpatuhan Pajak, Norma Subjektif, dan Kontrol Perilaku yang Dipersepsikan terhadap Niat Wajib Pajak Orang Pribadi untuk Melakukan Penggelapan Pajak. Universitas Kristen Petra.

Muzakki, Muadz Rizki. 2015. Pengaruh Corporate Social Responsibility Dan Capital Intensity Terhadap Penghindaran Pajak. Universitas Diponegoro.

Ngadiman. Puspitasari, Chirstiany. 2014. Pengaruh Leverage, Kepemilikan Institusional, Dan Ukuran Perusahaan Terhadap Penghindaran Pajak (Tax Avoidance). Universitas Tarumanegara.

Nuraina, Elva. 2012. Pengaruh Kepemilikan Institusional Dan Ukuran Perusahaan Terhadap Kebijakan Hutang Dan Nilai Perusahaan. IKIP PGRI Madiun.

Nuraini, Novia Suci. 2014. Analisis Faktor-Faktor Yang Mempengaruhi Thin Capitalization Pada Perusahaan Multinasional Di Indonesia. Skripsi Diponegoro University.

Oktofian, Muhammad. 2015. Pengaruh Corporate Governance Terhadap
Tax Avoidance. Skripsi UIN Syarif Hidayatullah Jakarta.

Pristyanova, Astrid. 2017. Pengaruh Pemanfaatan Tax Heaven, Transfer Pricing, Thin Capitalization Dan Struktur Kepemilikan Saham Terhadap Penghindaran Pajak (Tax Avoidance) Perusahaan. Skripsi Mercu Buana University.

Purwanggono, Erlang Anugrahendra. 2015. Pengaruh Corporate Social Responsibility Dan Kepemilikan Mayoritas Terhadap Agresivitas Pajak. Diponegoro University.

Rahayu, Ning. 2010. Praktik Penghindaran Pajak Oleh Foreign Direct Investment Berbentuk Perseroan Terbatas Penanaman Modal Asing. E-Jurnal Program Pascasarjana Universitas Indonesia.

Riadi, Edi, 2014.Metode Statistik: Parametrik \& Nonparametrik. Tangerang, Pustaka Mandiri.

Saputri, Rizki Andika. 2016. Pengaruh Tunneling Incentive Dan Pajak Penghasilan Terhadap Keputusan Perusahaan Untuk Melakukan Transfer Pricing. Skripsi Pamulang University.

Sugiyono, 2013. Metode Penelitian Kuantitatif, Kualitatif, dan $R \& D$. Bandung, Alfabeta.

Zelmiyanti, Riri. 2016. Pendekatan Teori Keagenan Pada Kinerja Keuangan Daerah Dan Belanja Modal. Universitas Islam '45 Bekasi.

Zuesty, Aisha. 2016. Pengaruh Kepemilikan Institusional, Risiko Perusahaan, Dan Leverage Terhadap Tindakan Tax Avoidance. Skripsi UIN Syarif Hidayatullah Jakarta. 